\title{
White Corporate Philanthropy and Its Support of Private Black Colleges in the 1960s and 1970s
}

\section{Marybeth Gasman}

is an associate professor in the Graduate School of Education at the University of Pennsylvania.

\section{Noah D. Drezner}

is an assistant professor in the College of Education at the University of Maryland, College Park.

\author{
Abstract \\ This paper traces the rise of corporate \\ philanthropy in terms of its support of \\ Black colleges, explores financial \\ support overall of Black colleges \\ during the 1960s and 1970s, and \\ describes the relationships between \\ corporations and private Black college \\ leaders. \\ International Journal of Educational \\ Advancement (2008) 8, 79-92. \\ doi:10.1057/ijea.2008.14
}

Keywords:

historically Black College \& University, philanthropy, corporations

In a sense, educational reality has been reversed: Black colleges, with the most difficult educational burden, always receive the most meager support, while colleges whose students are the most

\footnotetext{
Author's Contact Address:

Marybeth Gasman

Graduate School of Education

University of Pennsylvania

3700 Walnut Street

Philadelphia

PA 19104, USA

Phone: +1215 5733990

Fax: +1 2155736069

Email: mgasman@gse.upenn.edu
}

advantaged and advanced received the lion's share of available educational funds. (Daniel C. Thompson, 1973)

Although much has been written about White industrial philanthropy and early Black colleges (Anderson, 1988; Anderson and Moss, 1999; Watkins, 2001), historians have rarely explored philanthropy and its role within the Black college context in the 1960s and 1970s. And, most examinations of philanthropy have focused on foundation contributions, rather than those by corporations. Interestingly, as foundation philanthropy to Black colleges waned during the time period under discussion, corporate philanthropy (i.e., money given directly from corporations) increased (Gasman and Drezner, 2007). However, even these increased contributions to Black colleges did not approach the level of corporate giving to White colleges.

To understand corporate philanthropy in the 1960s and 1970s, we used the Oram Group fund-raising papers (located at Indiana University's Philanthropic Studies Library), the United Negro College Fund Papers (located at the Library of Congress), 
the Black college oral history collection at Columbia University, and archival data from Giving USA. In this paper, we will trace the rise of corporate philanthropy, explore financial support overall of Black colleges during the 1960s and 1970s, and describe the relationships between corporations and private Black college leaders.

\section{Corporate Philanthropy on the Rise}

By the 1960s, corporate philanthropy had become a major force in American society, having started in full during World War I (Clement, 1966; Wren, 1983). According to historian Scott Cutlip, "the modern corporation has slowly, often grudgingly, come to accept the social responsibility that its power and place in our society impose upon it. Part of this responsibility is discharged through gifts to public causes" (Cutlip, 1965, p. 151). Prior to World War I, the "business machine" did not support social causes in any significant way; instead, a "few millionaires" supported the nation's large-scale philanthropic efforts (Cutlip, 1965, p. 151). These millionaires pressured businesses to give. Initially, corporate attorneys were hesitant about corporate philanthropic giving; they worried that stockholders might not approve of the contributions nor the types of charities they supported. ${ }^{1}$

In addition, the government required that corporations report statistics on their gifts, which was burdensome for the companies. Scott Cutlip found that, "The immediate effect [on corporate giving] was not dramatic, for reported contributions averaged only $\$ 30$ million annually for the years
1936 through 1939" (Cutlip, 1965, p. 329). Most corporations did not take advantage of the federal government's deduction provision, made law in 1935. It was not until World War II, helped along by an increase in professional fundraisers, wartime pressures, and excess profits, that corporate giving had become a staple in most American cities (Cutlip, 1965). Additionally, comprehensive accounting of corporate giving to colleges and universities by the US Office of Education was not established until 1949 (Smith, 1983). A few historians claim that corporate giving increased during the post-war period because of a growing fear of "creeping socialism," especially after Harry Truman's surprise defeat of Thomas Dewey in 1948 (Cutlip, 1965, p. 51; Gasman, 2007a).

Scott Cutlip contends, during this time, a corporate executive would typically issue a statement like this one: "Corporations are part of the community in which [we] operate, and [we] owe to the community a duty equal to that of any individual who gains his livelihood there" (Cutlip, 1965, p. 510). Businessmen were interested in spreading good will (or at least the appearance of it) and as a result, creating and maintaining an environment "favorable to the profitmaking enterprise" (Cutlip, 1965, p. 510; Burlingame and Young, 1996). Further, in 1954 the General Electric Company (G.E.) established the first corporate matching gift program. Through this program G.E. matched qualifying gifts to nonprofits made by their employees. Higher education institutions, then as today, were the largest recipients of these matching funds (Smith, 1983; Peterson, 2005). 
The public responded positively to corporate philanthropy, with 44 states enacting laws authorizing corporate giving by 1960 (Cutlip, 1965; Burlingame and Young, 1996).

Of importance, many corporations and their leaders played strong roles in college fund-raising drives. Higher education benefited greatly from corporate giving-in some part, because religious entities were rarely an option for corporations due to the emotional and personal nature of these gifts and the risk of alienating certain customers segments. Of course, corporations' giving to education rather than religion was a dramatically different giving pattern than that of gifts by individual donors. Gifts to religion were the most common type among individuals. According to the National Industrial Conference Board, in the early 1960s, 39 percent of corporate giving went to education and most of it was allocated to colleges and universities (Cutlip, 1965, p. 513). The Council for Financial Aid to Education reported in 1962 that over $\$ 200$ million was given to higher education for operating and capital costs, with elite, private, research universities receiving more than onethird of this amount (Cutlip, 1965; Smith, 1983, p. 158). ${ }^{2}$ Public research universities received approximately 25 percent of the corporate funds, with the rest going to private colleges. In the words of one corporate leader, "Capitalism and free enterprise owe their survival to our private independent colleges. Just as private industry has given us material weapons with which to repel the armies of foreign aggressors, so we have looked to our privately endowed education for the intellectual weapons to resist invasion by totalitarian ideologies" (Irving S. Olds, former chairman of US Steel, in Cutlip, 1965, p. 517). As this was the height of the Cold War era, it was not surprising that the private colleges used similar language in their appeals to corporations. Fund-raising brochures extolled these institutions as being "the bulwark of our free economy" and the "most productive source of leaders and thinkers" (Cutlip, 1965, p. 517).

During the 1960s, regardless of how much public college officials complained, they received little support from the nation's corporations.

According to Scott Cutlip, corporations could easily rationalize their decision not to support public higher education. They would simply state that they "must support the nation's 'free and voluntary' institutions against the encroachment of Big Government" (Cutlip, 1965, p. 520). Moreover, most corporate leaders rebuffed fundraisers from public institutions, claiming that they were already giving to public higher education through their taxes. Nevertheless, a few public institutions were successful in convincing corporations to support their efforts; however most of this support was for research only.

\section{The Financial Support of Black Colleges during the 1960s and 1970s}

During the decades after the Brown $v$ Board decision, Black colleges faced a difficult situation, experiencing widespread deficits, low endowments, fund-raising struggles, and increasingly under prepared students (Gasman, 2007a). With the struggle for racial 
integration taking place throughout the country, securing support for an "allBlack" institution became increasingly difficult for the leaders of Black colleges (Gasman, 2007a). According to William J. Trent Jr., executive director of the United Negro College Fund (UNCF), by the early 1970s, 31 of the private black colleges were operating with deficits totaling 7.5 million dollars; the remaining six UNCF colleges either broke even or had miniscule surpluses (Trent, 1971; Holsendolph, 1971; Thompson, 1973). Endowment size was dangerously small, with all of the private Black colleges belonging to the UNCF having endowments adding up to a mere $\$ 72,250,000$. Even more troubling in these numbers; however, was the fact that five of the private colleges held "62 percent of these funds" (Trent, 1971, p. 456). Between 1954 and the mid-1970s, endowment values declined for Black colleges (Drewry and Doermann, 2001). Of course these rising deficits and low endowments were not caused in full by the fall of legalized segregation; Black colleges had operated "on the proverbial 'shoestring' since their inception" (Thompson, 1973, p. 247). Yet, Black colleges' problems were exacerbated by changes throughout the United States and the embrace of desegregation by most liberals.

Meanwhile, the foundation world was typically giving to "academic strengths (affluence) rather than to weaknesses (poverty)" (Thompson, 1973, p. 247). During the early 1960s, for example, only 2 percent of the support that foundations gave to higher education went to Black colleges and universities (Thompson, 1973). By the end of the 1960s, foundations were only contributing 0.7 percent of their annual allocation to higher education to these struggling institutions. Because a typical Black college received 2 percent of its budget from foundations, this decline had a pronounced negative effect (American Council of Education, 1969).

During these decades, the majority of grants to private Black colleges were made by six foundations: Ford, Kresge, Pew, Kellogg, Mott, and Mellon (Drewry and Doermann, 2001). The Ford Foundation gave substantially more than the others to Black colleges, but shortly after Brown, the powerful foundation directed its contributions to just a few of these institutions: Atlanta, Fisk, and Dillard universities. ${ }^{3}$ Leaders of the Ford Foundation, for example, believed that it was best to concentrate funding on those institutions with the greatest capacity-those that were the strongest (Kimball, 1981; Ford Foundation, 1955-1980). These better-off institutions were seen as having the potential to recruit White students, and thus, most likely to integrate (Mays, 1987; Ford Foundation, 1963-1971).

The federal government's funding policies, too, were not favorable to Black colleges. Although the government increased its support for these institutions during the 1960s, comparisons to its support of historically White institutions reveal widespread discrimination (American Council of Education, 1969). According to sociologist Daniel C. Thompson,

The federal government tends to deemphasize the role of Black colleges in its concern to promote 
the general welfare of this nation. Despite the fact that practically all of their students suffer from major socio-economic disadvantages. Black colleges are somehow expected to miraculously transform them into creative citizens.... About all private Black colleges are caught up in an impossible vicious cycle: they can't get essential help because they do not measure up-and they can't measure up without essential help. (Thompson, 1973, p. 247)

An examination of federal grant programs during the 1960s shows that only 3 percent of the government's total allocation went to Black colleges (American Council on Education, 1969). Of note here is that in many cases, in order to meet requirements for matching funds, Black colleges had to divert funding from important student-related programs. The need for Black colleges to steal from their own programs to secure government funds did indeed contribute to the "vicious cycle."

Although there were obvious discrepancies between the federal funding of Black and White institutions of higher education, many Black colleges nevertheless, "would not have survived to the end of the 1970s without the direct and indirect assistance provided by several new federal programs" (Drewry and Doermann, 2001, p. 106). For example, Black colleges received funds through the National Defense Education Act (1958), focusing on programs in science, mathematics, and language. In another instance, the Higher Education Act of 1965 provided Basic Education Opportunity Grants to needy African American students-in effect helping Black colleges. And, Title III of the Higher Education Act, which focused on developing institutions, assisted with faculty and academic programs and student services at Black colleges (Drewry and Doermann, 2001).

Black colleges also experienced discrimination in the support that they received from predominantly White churches. Typically, these churches gave Black colleges 60 percent less than they did the White colleges affiliated with their denominations (Bender, 1971; Task Force on Higher Education, 1969). Although there are probably myriad reasons why a church would give considerably more support to its historically White-affiliated colleges, an interest in promulgating integration (and thus starving "segregated" institutions) was a common factor (Gasman, 2007a).

During the 1960s and 1970s, Black colleges had little contact with individual Black donors. Many Black colleges had assumed because of wage inequities that an official campaign among their alumni would not result in any donations (Gasman and Anderson-Thompkins, 2003). ${ }^{4}$ Most Black colleges were just beginning to add development offices, alumni secretaries, and fund-raising personnel. However, the growing Black middle class provided a ready group of potential donors, including some people who could make major gifts and bequests. Interestingly, according to data from the United Negro College Fund, Blacks had been donating to their alma maters for years, but not in an organized fashion (UNCF Institutional Fundraising Surveys, 1944-1970).

Adding to the difficulties experienced by Black colleges during the 1960s and 1970s was the changing 
nature of the students that these institutions were enrolling-80-95 percent of whom were low-incomeand the growing enrollments of students overall (Thompson, 1973). With an increasing number of historically White institutions opening their doors to African American students, Black colleges could not compete in terms of scholarships, facilities, and variety in academic programs. Affluent (and in effect, often better prepared) Black students, by and large, fled to historically White institutions in the North (Drewry and Doermann, 2001; Thompson, 1973). As could have been predicted, White students were not enrolling in any significant number at Black colleges (Drewry and Doermann, 2001). As such, Black colleges were faced with raising scholarship money for lowincome students as well as funds for remedial programs for under prepared students. According to Henry Drewry and Humphrey Doermann, "enrollment in the forty-six private four-year colleges increased from roughly 30,000 in 1955 to 61,000 in 1975 ," with the vast majority of these students coming from low-income, Black households (Drewry and Doermann, 2001, p. 105). In the words of Drewry and Doermann, "Since small endowments and a large percentage of students needing financial assistance were characteristic of all private black colleges, enrollment growth always necessitated finding additional sources of revenue" (2001, p. 105).

\section{Corporate Support of Black Colleges}

In the words of fund-raising expert and president of the Oram Group, Harold Oram, corporations were the
"Johnny-come-latelies" to educational philanthropy (Oram Group, 1974a, p. 20). They were just beginning to focus on colleges and schools and in the past had spent most of their monies on social projects in the areas around their own manufacturing plants. The average gift to higher education for a corporation was between $\$ 5,000$ and $\$ 10,000$ in the mid-1960s through the mid-1970s (American Association of Fund-Raising Council, 1972, 1973, 1974; Cutlip, 1990). Following up on the 1964 Civil Rights Act, the federal government was pressuring corporations "to increase the numbers of blacks that they employ[ed] both in technology and in management" (Oram Group, 1974a, p. 21; Robinson, 2001; Loevy, 1990; Graham, 1992). As is the case today, most corporate donations at the time were made to colleges and universities that prepared significant numbers of their students to join the employee ranks of the donors' corporations. The new requirement that corporations hire more African Americans gave the Black colleges that were training them a certain "claim upon and access to [corporate] generosity" (Oram Group, 1965).

In reality during the 1960 s and 1970s, Black colleges could not expect to garner more than 20 percent of their income from corporations. And, the corporate industries that lent the most support were those in finance, retail, industrial manufacturing, transportation, and utilities (Oram Group, 1965). In contrast to historically White institutions, most corporate contributions to Black colleges were made from national rather than local or regional companies. Although "in a 
conventional [read White] university campaign, a high proportion of gifts is routinely raised in the community and region where the institution is located, this had not been commonly true for the black institutions, though there are significant exceptions [Howard University, for example]" (Oram Group, 1965). Because most Black colleges are located in the South, their relationships with the local corporations and citizens were complicated. Given the volatile time period of the 1960s and 1970s-and the role that some Black colleges had played educating civil rights leadersmany local corporations refused to support Black colleges and local citizens had a high level of disdain for these institutions and their "rowdy" students (Oram Group, 1965; Thompson, 1973). In addition, corporations shifted their giving practices during the 1970 s. In the past, they gave undesignated funds, which were attractive to colleges and universities wanting to have more autonomy in fund-raising relationships. However, by the 1970s, most corporations were allocating funds to specific programs. Often times, these programs had a direct connection to and benefit for the corporation (Oram Group, 1974a). For example, Hampton Institute received a $\$ 10,000$ grant in 1965 from the Union Carbide Corporation to support research and development of low-cost building materials (Hampton Institute, 1965). Upon development, any potential product would directly benefit the donor.

\section{Attracting corporate donors}

In an attempt to attract corporate attention and funds, Black colleges used language that appealed to corporate sensibilities. These institutions had a history of tweaking their language when needed in order to acquire funding (Gasman and Epstein, 2004; Gasman, 2003, 2004, 2007a).

A Morehouse College fund-raising brochure provides a representative example, stating “The Morehouse Man is a leader-a man of personal stature who gets things done. Morehouse leadership is making major contributions to law, medicine, politics, philosophy, science and sports. And it's also 'very good for business" (Oram Group, p. 1 undated). Many Black colleges would also use testimonials from prominent businessmen in their fund-raising brochures, with the hope of attracting more corporate dollars. Morehouse College included the words of Rex Adams, a vice president at Mobil Oil, to emphasize their unique preparation of African American men:

The Mobil Corporation is cutting back on the number of colleges at which we'll be recruiting by almost 75 percent. But we will be keeping Morehouse on the list. We see a spirit at Morehouse that's unlike that of almost any other school in the country.... Morehouse students are not only well prepared, but they are very highly motivated and eager to enter the business community.

(Oram Group, p. 1 undated)

Likewise, John Carter, president of The Equitable, provided the Morehouse fundraisers with excellent material:

We've had Morehouse students as summer interns at The Equitable for the past six years. These young men really hit the ground running. They come to us to learn and to "try 
their wings" in an actual business environment. But while they're here, they give us much more than we give them. They come in with tremendous self-confidence. They're ready, and willing, to assume responsibility right from the beginning. (Oram Group, p. 9 undated)

Black colleges were happy to point out that in the post-1964 era, corporations were required to diversify their staffs. Hampton Institute was blunt in its attempt to secure corporate dollars, beginning a solicitation letter with "Why can't your company find Negroes with college degrees?" The answer they provided was as follows: "Because only a small percentage of college-age Negroes ever get to college. Scholarship funds are limited. After school jobs don't pay enough. And families from which most Negroes come cannot afford even the moderate tuition and fees of predominantly Negro colleges like Hampton Institute" (Bunker, 1965). ${ }^{5}$ Of course, Hampton's plea spoke to the 1964 Civil Rights Act, which included mandates for corporations regarding employee diversification (i.e. affirmative action). Another letter, sent to "Equal Opportunity Employers" spoke even more directly to issues of affirmative action, noting "I hope you will agree that support of Hampton Institute's efforts to qualify Negro students for opportunities only recently open to them is as much the responsibility of sympathetic individuals as it is of business and industry" (Bunker, 1966a).

The above-mentioned letter went hand in hand with Hampton's brochure, designed to attract corporate support. The cover of the brochure, featuring a neatly dressed African American male working in a business environment (Oram Group, undated a). And, using the words of Lyndon B. Johnson, the United States president who signed the Civil Rights Act into law, the brochure continued, "It is not enough just to open the gates of opportunity. All our citizens must have the ability to walk through those gates" (Oram Group, undated a). Hampton went so far as to take out a full-page ad in the New York Times to attract corporate donors, reminding them that although "Negroes constitute 11 percent of the nation's population...[,] they were only 2.01 percent of its chemists, 2.46 percent of its dentists, 2.80 percent of its engineers, 1.45 percent of its scientists and 2.05 percent of its doctors. In fact, only 3.98 percent of all professional, technical and allied workers [were] Negroes" (Hampton Centennial Fund Ad, 1966; Bunker, 1966b, 1967; Oram Group, undated a). The more prominent Black colleges, including Morehouse and Hampton, were able to attract the leadership participation of nationally known corporations. For example, Donald Keogh, the president of Coca-Cola, was the Chairman of Morehouse College's fund-raising campaign in the 1970s (Oram Group, 1974b).

\section{Giving more to White colleges and Universities}

Corporate donations given to Black colleges were often less than those provided to their White counterparts. According to Benjamin Mays, the country as a whole was unwilling to put its full support behind Black 
colleges-this lukewarm attitude was demonstrated by the difficulties that the United Negro College Fund faced in launching a major campaign in the early 1960s. Black colleges, in the eyes of many, were considered vestiges of Jim Crow and as such not worthy of full support (Mays, 1987; Gasman, 2007a). According to the Oram Group, which raised money for over 20 Black colleges and many historically White institutions as well, "The major givers to black institutions are similar to those who give to other institutions.... The constituencies have not, however, supported black institutions in the same manner and in the same percentages that they have supported traditionally White institutions. Corporations began giving to education in general only in recent years and their new interest in black institutions has resulted as much from Federal and community pressure as anything else" (Oram Group, 1974a).

William J. Trent Jr., the Executive Director of the UNCF, tried to quantify disparities in corporate support to Black and White institutions of higher education. In a study that examined corporate and foundation giving to private Black colleges in the late 1950s and early 1960 s, Trent found that historically White colleges were awarded double that of their Black counterparts. Trent's sample included 41 White colleges and 41 Black colleges (Trent, 1960). In 1970, Dow Votaw and Prakash Sethi conducted a more comprehensive study on corporate and foundation giving to Black colleges. Their research showed results similar to Trent's study. According to Votaw and Sethi, "Both corporations and foundations, on a per student basis,
Table 1: Contributions per student by corporations to predominantly White and predominantly Black institutions, by type of institution, 1967 (Votaw and Sethi, 1970)

\begin{tabular}{lll}
\hline $\begin{array}{l}\text { Type of } \\
\text { institution }\end{array}$ & $\begin{array}{l}\text { Total } \\
\text { contributions- } \\
\text { White }\end{array}$ & $\begin{array}{l}\text { Total } \\
\text { contributions- } \\
\text { Black }\end{array}$ \\
\hline $\begin{array}{l}\text { Major private } \\
\text { Public }\end{array}$ & $\$ 115.54$ & $\mathrm{NA}$ \\
$\begin{array}{l}\text { Independent } \\
\text { Church-related }\end{array}$ & $\begin{array}{l}31.66 \\
75.12\end{array}$ & $\$ 7.39$ \\
All & $\$ 66.02$ & 52.47 \\
\hline
\end{tabular}

make substantially heavier donations to predominantly white public institutions than to the predominantly black public colleges." They also "make larger per student donations to predominantly white independent and church-supported schools" (see Table 1; Votaw and Sethi, 1970, p. 681).

Interestingly, all but a few thousand dollars from corporations were given to Black colleges for current expenditures. By and large, the majority of contributions to historically White institutions went to capital expenses (Votaw and Sethi, 1970).

As can be seen in Table 1, corporations gave four times as much to historically White public institutions than to their Black counterparts and twice as much to historically White private institutions than to private Black colleges. Votak and Sethi speculate that corporations were more likely to give to private Black colleges because of the political implications of giving to a "segregated" public institution. Moreover, they note that many corporations were angry that southern states were not supporting 
public Black colleges at equal levels to their White counterparts and as such refused to enable these states in their discriminatory behavior. ${ }^{6}$ Corporate leaders, especially those from the North, found the actions of the White legislatures in the South to be frustrating and disingenuous (Votaw and Sethi, 1970).

\section{Reasons for not giving to Black colleges}

There were many reasons why corporations did not give or stopped their giving to the nation's Black colleges during the 1960s and 1970s. Some corporations were critical of those Black colleges with low alumni giving percentages. By and large, during this time, Black college alumni contributions were small to miniscule mainly due to the lack of access to income and assets on the part of African Americans (Gasman and Anderson-Thompkins, 2003; Lui et al., 2006). ${ }^{7}$ As mentioned, however, giving rates were also low because alumni were rarely asked to give by their alma maters. For the most part, Black colleges had become dependent on foundation, and some corporate giving, over the course of their existence (Gasman and Anderson-Thompkins, 2003; Gasman, 2007a). For example, in 1965, Hampton Institute alumni contributed only 2.85 percent of the total funds contributed to the institution, Meharry Medical School alumni gave 2 percent of all contributions, and Howard alumni gave 4 percent (Oram Group, 1965). Historically White institutions boasted alumni giving rates of $15-25$ percent (Cutlip, 1965). During this time (and in the current day), a strong alumni giving percentage could influence corporate grants immensely, leading to contributions at the level of six and seven figures (Oram Group, 1965). This was the norm at most historically White institutions, which typically had strong alumni giving percentages. However, within the Black college setting, the gifts tended to be in the four and five figure range, with the exceptional six figure gift (Oram Group, 1965). For example, Oakwood College (Huntsville, AL) reported a $\$ 5,000$ corporate gift that would be given to the college when the institution successfully matched the gift with other solicited funds (Oakwood College, 1963).

Some corporate donors to Black colleges were frustrated by the lack of follow through once a contribution was made. The president of one national corporation, for instance, speaking anonymously to an Oram Group fund-raising consultant, noted that he made a "sizable grant to Atlanta University" but did not receive a thank you or progress report. Of course, he did receive these items from the three historically White institutions to which he had donated at the same time. He noted that receiving these materials made him more inclined to give again (Oram Group, 1974a). Conventional wisdom in the world of fund-raising states that "it is dangerous to view potential constituents as nothing more than sources of funds" (Oram Group, 1974a). According to the Oram Group consultants, in a report to Atlanta University, if the corporation "sees someone from an institution only when it needs money, if he is not thanked, sent program reports, bulletins, and an occasional visitor who is interested in what he 
thinks, he quickly turns cynical. He cannot be faulted for this because the institution clearly has a cynical view of him and his relationship. Such a relationship offers no pride of association and builds no loyalty" (Oram Group, 1974a).

One problem that Black colleges faced during this time was that they were seen as one entity rather than a diverse set of colleges with diverse needs (Gasman and Urban, 2008; Gasman, 2007b). Dillard University, for example, had significant difficulty securing funds from corporations during their 1970 s campaign because other Black colleges in the region, including Xavier University of Louisiana, were also launching campaigns. Often the leaders of both local and national corporations would respond to solicitations with, "I already gave to a Black college” (Oram Group, undated).

For those institutions that did not belong to the United Negro College Fund and even for those that did that were raising funds on their own (member colleges were permitted to raise funds for their own institutions during specific times of the year), many corporations hid "behind UNCF donations." When approached by the Black colleges, many corporations would simply say, "we already gave to the United Negro College Fund" and were not willing to send their money to specific Black colleges (Oram Group, 1965, p.14). When Hampton Institute decided to leave the UNCF in the 1960s and raise funds on their own, the Hampton Centennial Fund professional fund-raising organization told them, "no Trustee should assume for a moment that there are more grapes in the vineyard for Hampton
Institute, simply because it has decided to make wine alone." Oram added, "years of habituation to united funds, federated college appeals, UNCF, and higgledy-piggledy giving representing no clear-out policy at all will make corporate and foundation grantsmanship tough going" (Oram Group, 1965, p. 14).

Part of the problem, in the opinion of the Oram Group, was that "In dollars granted, corporate support of higher education still tends to favor the largest and most prestigious to anyone else"-of course, most Black colleges at this time were neither larger nor prestigious in the eyes of Whites (Oram Group, 1965, p. 14). Interestingly, when time came to evaluate the effectiveness of Black colleges, scholars, policy makers, and donors often used "large" and "prestigious" institutions as benchmarks against which Black colleges could be measured (Gasman, 2006).

\section{Conclusion}

In some cases the lack of corporate giving to Black colleges was caused by mistakes on the part of the institutions themselves, including lack of follow through after a contribution was made and failure to solicit alumni and secure their donations. But, Black colleges were in a bit of a conundrum when it came to their relationships with corporations. In order to generate corporate funds, they had to invest a lot of energy and time in these relationships-all the while knowing that because of their disadvantaged position (caused by racism and postBrown misconceptions) they were unlikely to ever garner as much money 
as their historically White

counterparts. Corporate philanthropists often gave less money to Black colleges than historically White institutions even though both asked for virtually the same contribution. Black leaders, interviewed in the $1980 \mathrm{~s}$, sensed that the corporate leaders were willing to give Black colleges "just enough to survive" but not to flourish. ${ }^{8}$

During the 1970s, as more African Americans were gaining access to historically White institutions, corporate leaders demanded a return on their investment, asking Black college leaders to prove the impact of their institutions on individual companies. As a result, corporations had increasing control of and influence on Black colleges. However, Black higher education had little influence within the walls of corporate America-unless one considers the small number of Black college graduates corporations employed. Although one can see parallels between early industrial philanthropy and more recent corporate philanthropy, such as the issue of control, those Black colleges trying to secure corporate dollars in the post-Brown and postCivil Rights Era faced unique questions, including why they existed at all at a time when Black students had other options and desegregation was on the march. Unfortunately, these questions continue to be asked today despite the unique and important contributions of the nation's Black colleges.

\section{Notes}

${ }^{1}$ In fact, in 1953 a stockholder challenged the concept of corporate giving. In a decision upheld by the New Jersey
Supreme Court, a lower court found that a gift of $\$ 1,000$ given by A.P. Smith Manufacturing Company to Princeton University was justified in that the contribution was "toward a cause which is intimately tied into the preservation of American business and the American way of life" (A. P. Smith $v$ Barlow, 1953). ${ }^{2}$ Hayden W. Smith found corporate support of higher education in 1961-62 to be $\$ 154$ million and $1962-63$ to be $\$ 169$ million. These numbers, although cited from the same source, Council for Financial Aid to Education, differ from Scott Cutlip.

${ }^{3} \mathrm{~A}$ review of annual reports between 1955 and 1980 demonstrates the Ford Foundation's commitment to a few Black colleges. Specifically, the reports state that Ford's Minorities in Higher Education Focus will provide "major developmental grants to a limited number of traditionally black, private colleges" (Ford Foundation Annual Reports). ${ }^{4}$ This salary differential also had an impact on how Black colleges benefited from the previously mentioned corporate gift matching programs.

${ }^{5}$ This is from one of roughly 200 letters sent to corporate leaders.

${ }^{6}$ Disparities in funding continues to exist for Black Colleges, especially in terms of state funding (Minor, 2008). ${ }^{7}$ This continues to be a problem for Black colleges in the current day. ${ }^{8}$ See UNCF leadership interviews and Black College presidential interviews located in the Columbia University oral History Collection, Columbia University, New York, NY.

\section{References}

American Association of Fund-Raising Council (1972), Giving USA: A Compilation of Facts and Trends on American Philanthropy for 1972, American Association of Fund-Raising Council, Glenview, IL. 
American Association of Fund-Raising Council (1973), Giving USA: A Compilation of Facts and Trends on American Philanthropy for 1973, American Association of Fund-Raising Council, Glenview, IL.

American Association of Fund-Raising Council (1974), Giving USA: A Compilation of Facts and Trends on American Philanthropy for 1974, American Association of Fund-Raising Council, Glenview, IL.

American Council on Education (November 3, 1969), Higher Education and National Affairs, American Council on Education, Washington, DC, 18.27.

Anderson, J.D. (1988), The Education of Blacks in the South, 1860-1935, University of North Carolina Press, Chapel Hill, NC.

Anderson, E. and Moss, A. (2001), Dangerous Donations, University of Missouri Press, Columbia, MO.

A.P. Smith Manufacturing Co. $v$ Barlow, 13 N.J. 145; 98 A. 2 d 581.

Bender, R.N. (ed.) (1971), The Church Related College Today: Anachronism or Opportunity, The General Education Board, The United Methodist Church, Nashville, TN.

Bunker, E. (November 29, 1965), Hampton Centennial Fund to William J. Porter, President of Wetter Numbering Machine Company in Oram Group Papers, Housed at the IUPUI Library, Ruth Lilly Special Collections and Archives.

Bunker, E. (March 14, 1966a), Hampton Centennial Fund to Ellery C. Huntington, Jr. in Oram Group Papers, Housed at the IUPUI Library, Ruth Lilly Special Collections and Archives.

Bunker, E. (December 9, 1966b), Hampton Centennial Fund to A.G. Paine in Oram Group Papers, Housed at the IUPUI Library, Ruth Lilly Special Collections and Archives.

Bunker, E. (January 13, 1967), Hampton Centennial Fund to Robert R. Willims in Oram Group Papers, Housed at the IUPUI Library, Ruth Lilly Special Collections and Archives.

Burlingame, D. and Young, D.R. (eds.) (1996), Corporate Philanthropy at the Crossroads, Indiana University Press, Bloomington, IN.

Cutlip, S. (1965), Fund Raising in the United States: Its Role in America's Philanthropy, Rutgers University Press, Brunswick, NJ.

Cutlip, S. (1990), Fundraising in the United States, Transaction Press, Piscataway, NJ.

Clement, R.E. (1966), "The historical development of higher education for Negro Americans," The Journal of Negro Education, 35, 299-305.

Drewry, H. and Doermann, H. (2001), Stand and Prosper: Private Black Colleges and Their
Students, Princeton University Press, Princeton, NJ.

Ford Foundation (1955-1980), Ford Foundation Annual Reports. Accessed from www. fordfoundation.org/elibrary.

Gasman, M. (2003), “A word for every occasion: Appeals by John D. Rockefeller, Jr. to white donors on behalf of the United Negro College Fund," in History of Higher Education Annual, Vol. 22, Johns Hopkins University Press, Baltimore, pp. 67-90.

Gasman, M. (2004), "Rhetoric vs. reality: The fundraising message of the United Negro College fund in the immediate aftermath of the Brown decision," History of Education Quarterly, 44, 70-94.

Gasman, M. (2006), "Salvaging 'academic disaster areas': The black college response to Christopher Jencks' and David Reisman's 1967 Harvard Educational Review article," Journal of Higher Education, 77, 317-352.

Gasman, M. (2007a), Envisioning Black Colleges: A History of the United Negro College Fund, Johns Hopkins University Press, Baltimore.

Gasman, M. (2007b), "Truth, generalizations, and stigmas: An analysis of the media's coverage of Morris Brown College and black colleges overall," Review of Black Political Economy, 34, 2, 111-135.

Gasman, M. and Anderson-Thompkins, S. (2003), Fund Raising from Black College Alumni: Successful Strategies for Supporting Alma Mater, CASE Books, Washington, DC.

Gasman, M. and Drezner, N.D. (2007), “A maverick in the field: Fundraising for change in the black college community during the 1970s," History of Education Quarterly (Forthcoming).

Gasman, M. and Epstein, E. (2004), "Creating an image for black colleges: A visual examination of the United Negro College Fund's publicity, 1944-1960," Educational Foundations, 18, 2, 41-61.

Gasman, M. and Urban, W.J. (2008), "Putting to rest Brown v. Board's stigma of racial inferiority: A framework for viewing black colleges," in L. Perkins (ed.), Race and Higher Education: Forging a New Research Agenda, Johns Hopkins Press, Baltimore.

Graham, H.D. (1992), Civil Rights and the Presidency: Race and Gender in American Politics, 1960-1972, Oxford University Press, New York.

Hampton Centennial Fund Ad (1966, November 29), "Full Page Ad," New York Times, n.p.

Hampton Institute (1965), Hampton Institute 1965 Report to UNCF, Hampton Institute, Library of Congress, Washington, DC. 
Holsendolph, E. (1971, October), "Black colleges are worth saving," Fortune, 64, 4, 104-107; $118-122$.

Kimball, L. (1981), Interview by Marcia Goodson in the United Negro College Fund Oral History Collection, Columbia University Oral History Collection.

Loevy, R. (1990), To End All Segregation: The Politics of the Passage of the Civil Rights Act of 1964, University Press of America, Latham.

Lui, M., Anderson, R., Lenodar-Wright, B., Robles, B. and Brewer, R. (2006), The Color of Wealth: The Story Behind the U.S. Racial Divide, The New Press, New York.

Mays, B. (1987), Interview by Marcia Goodson in the United Negro College Fund Oral History Collection, Columbia University Oral History Collection.

Minor, J.T. (2008), Contemporary HBCUs: Considering Institutional Capacity and State Priorities, Michigan State University, College of Education, Department of Educational Administration, East Lansing, MI.

Oakwood College (1963), Oakwood College 1963 Report to UNCF, Oakwood College. Housed at the Library of Congress.

Oram Group (undated a), Hampton Centennial Fund. In Oram Group Papers, Housed at the IUPUI Library, Ruth Lilly Special Collections and Archives.

Oram Group (undated b), Morehouse College. An Exceptional Investment for the Future. In Oram Group Papers, Housed at the IUPUI Library, Ruth Lilly Special Collections and Archives.

Oram Group (undated c), A Study of Fund-Raising Readiness and Feasibility Prepared for Dillard University. In Oram Group Papers, Housed at the IUPUI Library, Ruth Lilly Special Collections and Archives.

Oram Group (1965), Report to Black Colleges. In Oram Group Papers, Housed at the IUPUI Library, Ruth Lily Special Collections and Archives.
Oram Group (1974a), Morehouse Transition Campaign. In Oram Group Papers, Housed at the IUPUI Library, Ruth Lilly Special Collections and Archives.

Oram Group (1974b), Atlanta University Study of Fund-Raising Feasibility, Atlanta University, Unpublished archival file, Housed at Ruth Lilly Special Collections and Archives, IUPUI Library, Indianapolis, IN.

Peterson, E. (2005, January), "Fifty years after their debut, corporate matching gift programs continue to evolve," CASE Currents, 31, 1, 32-37.

Robinson, J.A. (2001), Affirmative Action: A Documentary History, Greenwood Press, Westport, CT.

Smith, H.W. (1983), “The outlook for corporate financial aid to higher education," Proceedings of the Academy of Political Science: The Crisis in Higher Education, 35, 2, 157-172.

Task Force on Higher Education (1969, July 25), "Black Methodists for church renewal. Washington, DC.

Thompson, D.C. (1973), Private Black Colleges at the Crossroads, Praeger, Westport, CT.

Trent Jr., W.J. (1971), "The Negro college and its financing," Daedalus, 100, 3, 647-659.

United Negro College Fund (1944-1970), Institutional Fundraising Surveys. United Negro College Fund Archives, Robert Woodruff Library, Atlanta University Center, Atlanta, GA.

Votaw, D. and Sethi, S.P. (1970), "Some paradoxes in the support of predominantly black colleges," The Journal of Higher Education, 41, 673-694.

Watkins, W. (2001), White Architects of Black Education, Teachers College Press, New York.

Wren, D.A. (1983), "American business philanthropy and higher education in the nineteenth century," The Business History Review, 57, 321-344. 